\title{
A Case Study: Policy Communication at Postgraduate Program Academic Service of Public Service
}

\author{
Ismandianto, Faisyal Rani \\ Jurusan Komunikasi FISIP Universitas Riau \\ e-mail: ismandianto@ lecturer.unri.ac.id
}

\begin{abstract}
This research aims at describing the factors influence the policy communication at Postgraduate Program Academic Service of Public Service unit of Politic and Social Science Faculty of Riau University. The method of this research is qualitative with purposive sampling technique used. The sample of the research is the persons who know and involved in the academic service of Politic and Social Science Faculty of Riau University. The data were collected by documentation, interview, and observation. The data were analysed by using descriptive qualitative technique which focus on the particular object intensively. The finding of the research shows that policy communication implementation in Academic Service Unit was poor. It caused by the unbalance ratio of lecturer and students, lack of facilities maintenance, and there is no Standard Operational Procedure (SOP) in administration implementation, and the lack of monitoring and evaluation quality applied by the Faculty management. The factors influenced this policy communication were facilities and infrastructures, qualified human resources availability, Standard Operational Procedure (SOP) availability, students' capacity management, students' study road map service availability, course service and course monitoring implementation availability.
\end{abstract}

Keywords: Communication, policy, academic service administration, public service unit

Abstrak
Penelitian ini bertujuan untuk mendeskripsikan, menganalisis dan meneliti faktor yang mempengaruhi komunikasi kebijakan bidang layanan akademis Fakultas Ilmu Sosial dan Ilmu Politik Pasca Badan Layanan Umum (BLU) Universitas Riau. Penelitian ini menggunakan metode kualitatif, pemilihan informan dilakukan dengan teknik purposive sampling. Informan yang diteliti adalah orang yang benar-benar tahu dan terlibat langsung dalam penelitian bidang layanan administrasi akademik. Teknik pengumpulan data dengan cara studi dokumentasi, wawancara dan observasi. Kesemua data yang diperoleh akan dianalisis dengan cara deskriptif kualitatif, memusatkan perhatian secara intensif terhadap suatu objek tertentu dengan mempelajarinya secara kasus. Hasil penelitian menunjukkan bahwa pelaksanaan komunikasi kebijakan bidang layanan akademis kurang terimplementasi dengan baik di Fakultas Ilmu Sosial dan Ilmu Politik Pasca Badan Layanan Umum (BLU) Universitas Riau dikarenakan, timpangnya rasio dosen dengan mahasiswa, kurang termaintenancenya prasarana yang tersedia, tidak ada SOP dalam layanan administrasi, tidak jalannya team monev Fakultas dengan baik. Sedangkan faktor-faktor yang mempengaruhi kebijakan komunikasi diantaranya ketersediaan sarana, ketersediaan tenaga yang berkompeten, ketersediaan pedoman dan prosedur layanan, penyusunan daya tampung mahasiswa, ketersediaan layanan perencanaan studi mahasiswa, ketersediaan layanan perkuliahan dan monitoring pelaksanaan perkuliahan.

Kata Kunci : Komunikasi, Kebijakan, Layanan Administrasi Akademik, Badan Layanan Umum 


\section{INTRODUCTION}

Government is public servant because they have responsibility to give qualified and professional service to the society. Public service implementation is a manifestation of state apparatus as the civil servant to welfare the society.

According to Ministerial Decree of Empowerment of State Apparatus, No. 63/KEP/M.PAN/7/2003, public is all service activity implemented by public service servant as an effort to fulfill the service recipient and laws and regulation implementation. Furthermore, public service is society's interest fulfillment by state organizer. A country is founded by public with purpose to improve the society's prosperity. So, a country which is represented by government must be able to fulfill the publics' interest such as health service, education service, etc.

Public service implementation is a main indicator of the real government's performance in implementing the service. Public can directly evaluate the government's performance based on the public service quality accepted because it influences the society's satisfaction. In another word, the success of professional, effective, and accountable public service implementation will improve the government's image. So, it needs a great concern from all parts such as government as the regulation maker, state apparatus as the organizer, and public as the supervisor of public service implementation as mandated by the institution.

One of the functions of main public bureaucracy is establishing the communication to public as well as possible. The effective policy communication is an indicator for implementing the service and evaluating the service quality. It is the commitment of government to implement quality service for public.

Furthermore, public service is the fulfillment of public affairs by state organizer because a country is founded by public with purpose to improve the society's prosperity. So, a country which is represented by government must be able to fulfill the publics' interest such as health service, education service, etc.

As far, Public says that government is lack of efficient and effective in implementing the public service. Otherwise, they must be capable of implementing the professional, accountable, and transparent service in this modern management era. Max weber, a modern sociologist, says that government has an important role in governmental implementation. Government functions as a regulator and administrator (mechanic view) and as the public service agency and investor (organic view). Government function as regulator and administrator relates to bureaucracy. While, as the service agency and investor, government should be dynamic and able to be transformed to an autonomous unit.

Institutions in government area which is formed to implement the public service in providing goods and or services sold without benefit based on the efficiency and productivity principle (clause: 1, regulation No. 1 / 2004: treasury of state).

Budgeting based performance is stated in the regulation No. 17, 2003, about State Finances and regulation No. 1, 2004, about State Treasury, Article: 68 and 67, present the current guidance. It describes that government institution which is implementing the public service may applied the flexible financial management method concerns to the productivity, efficiency, and affectivity.

Both regulations above are the basic principle for the government to implement the public service unit financial management. Public service unit is expected to be the leader of the management reformation of public service finances. It aims at improving the public service implementation.

Public service unit is an institution in the central government area aims to give service to public in providing goods and or service which is sold without benefit based on the efficiency and productivity principle.

Government Regulation No. 23, 2005, about Public Service Unit Financial Management, gives the opportunity to the government institution to implement this system. It aims to improve the public service 
implementation. It also applies flexibility principle in implementing the service. So, flexibility has an important role in public service unit administration of Riau University.

University of Riau is one of educational institution in Riau. It has a crucial role in improving education in Riau. In establishing vision and mission, it needs a lot of support from many aspects such as regulation, qualified and quality human resources, facilities and infrastructures, work environment, etc. So that University of Riau is able to reach the goal.

Formerly, University of Riau is an educational institution belonged to government without Minimum Service Standard. Generally, it had no service indicator as the standard for the academic staffs in implementing a prime service. Recently, University of Riau is a Public Service Unit belongs to the government. It must implement the service with Minimum Service Standard. It is one of the administration requirements for every Public Service Unit. By implementing this Minimum Service Standard, University of Riau is expected to implement prime service to the publics.

University of Riau which was founded on 1 of October, 1962, should be able to educate the publics so they will be skillful and professional. Unfortunately, University of Riau accepts limited numbers of students because of the regulation.

Furthermore, Politic and Social Science Faculty of University of Riau was obliged to accommodate the public aspiration and needs of further education especially for them whom were living in Riau Province.

The organization of education in Politic and Social Science Faculty is a part of education system in University of Riau. It goes along with the National Education of Education and Culture Ministry.

Politic and Social Science Faculty of Riau University has been improving its quality day by day. It has purpose to give the best and excellent service to all of academic communities. So, it needs a service procedure and policy communication.

Policy communication is the main indicator and standard of quality for the whole service given. The standard of policy is stated in the Minimal Service Standard of Riau University. It states that the Politic and Social Science Faculty is accountable and transparent in institution management.

The rector of Riau University has stated a team work to make Standar Operasional Prosedur (SOP) which concerns to the quality of accountable and transparent service implementation. It is stated on the decree of Rector of Riau University No. 225/H19/TU/2009, $19^{\text {th }}$ of May, 2009. In Minimal Service Standard implementation in Academic Administration Service Unit, the prosecutors are Bureaus of Academic Administration Service in Riau University such as Academic Administration and Students Affairs Bureau in the level of University and Academic Administration Unit in the Faculty. Besides that, there are several bureaus relate to the Minimal Service Standard implementation in Academic Administration Service Unit such as Registration and Statistic and Education and Cooperation Unit of Riau University which coordinates with Monitoring and Evaluation Unit of Riau University. These whole units are under the Vice Rector I Responsibility.

In conclusion, Riau University should consider the simplicity, accuracy, and velocity principles in conducting public service implementation especially in Academic Administration Service Unit. Unfortunately, the implementation of public service in Politic and Social Science Faculty is not qualified enough. Some phenomenon of this research were found, they are:

1. The service takes too long time and the staffs are unfriendly when serving the students.

2. The lack of communication between team teaching-lecturers in grading the students. So, there is a different grade found in the same subject.

3. The lack of trust between team teaching-lecturers in carrying out the course. So, the students have to join unscheduled class designed by the responsible lecturer. 
4. Almost of all lecturers have lack of discipline in submitting the students' grade to the staffs of Academic Information System. It is not as stated in the decree of the Rector No.

648/H19/AK/2010, 8 of December 2010, about final test result:

a) The due date of grade submitting is nine days after carrying out the test.

b) The final score submitted cannot be changed.

c) If there is a mistake in giving the score, there should be an acceptable reason written down in a form to change it.

5. Unorganized archives of students' grade. It makes the former and alpha-study students hard to find the data needed.

6. The length time of transcripts' and certificate's printing where the students' need it.

7. The lack of policy communication between Faculty administration and communication center in solving the problems faced during the students' academic requirements fulfillment such as course inputting or score inputting.

Policy implementation is a way to reach the goal. Meriles S. Grindle in Riant Nugroho (2004:174) states that the success of policy implementation is determined by two variables. They are content of policy and context of policy.

Based on that theory, it is very crucial to discuss about content of policy and context of policy of Minimum Service Standard policy of Riau University which is stated in the government regulation No. 23, 2005 about Public Service Unit Financial Management. Chapter III, clause 4 says that the administrative requirement in implementing public service unit in Riau University is Minimum Service Standard implementation. It is also stated in the Regulation of National Education Ministry No. 51, 2009.

The aim of Public Service Unit is to administer the duty and role of Riau University in implementing the service to students or public based on the Minimum Service Standard. Unfortunately, the implementation of public service in Politic and Social Science Faculty is not qualified enough. Pertaining to the phenomenon, the researcher is interested in conducting a research relates to policy communication in Academic Unit.

\section{METHOD}

This research was qualitative. It aims at finding the facts to be concluded. The researcher was the human instrument who adapted his self to all of the realities arose. It intended to reveal the problem in deep. This research used some respondents determined by purposive sampling technique. It is based on the subject's ideas relates to the problem, having accurate data, and able to share complete and accurate information. The key informant of the research was the Vice Dean of Academic affairs, head of administration, head of academic unit, head of departments, and lecturers. The data were collected by using documentation, interview, and observation.

\section{FINDING AND DISCUSSION}

\section{Policy Communication of Academic Affair in University}

Based on the interview result, it was found that human resources were an important factor in policy communication implementation in Riau University. One of the indicators for the optimal achievement is Minimum Service Standard of Riau University. It is a commitment of Riau University to improve the service implementation. It should consider to service's quality, service's equality, service's budget, and easiness to have the service. It can be one of the references for budgeting. 
This following script is the result of interview from Mr. Burhan, the staff of Cooperation and

Development Unit of Riau University.

"“sepengetahuan saya sebagai staf disini SPM yang disusun oleh Tim BLU memang sudah disosialisasikan kepada pegawai administrasi seluruh lingkungan UR. SOP yang disusun oleh BKP juga telah kami berikan kepada pihak-pihak yang melaksanakan pelayanan terutama dibidang pelayanan administrasi akademik agar mereka memiliki pedoman dalam pelaksanaan pelayanan.

There is a different implementation of Minimum Service Standard among the staffs. It can be seen from the interview with Mr. Benyamin Franklin, the chairperson of Education and Cooperation Unit.

“ dalam pelaksanaan pelayanan idealnya memang harus ada standar pelayanan yang menjadi dasar dalam pelaksanaan pelayanan oleh seluruh pegawai di lingkungan UR, hanya saja pihak Universitas sendiri belum memiliki standar prosedur yang disusun sedemikian rupa berupa kesatuan dalam bentuk buku. Yang kami miliki hanya selembaran Standar Operasional Prosedur yang memang ditandatangani oleh Kepala BAAK. Jadi secara keseluruhannya memang selama ini belum ada standar pelayanan yang tersusun dengan baik untuk kami jadikan pedoman baik itu dalam bentuk SPM maupun SOP. Atau mungkin sudah ada tapi belum sampai kepada kami. Jadi selama ini kami melaksanakan pelayanan administrasi baik untuk mahasiswa maupun pegawai sendiri segala sesuatunya mengalir begitu saja sesuai dengan kondisi dan situasi namun tidak menyimpang dari ketentuan yang terkait "

The management of education in Politic and Social Science Faculty is a part of education process system in Riau University. It goes along with the National Education system of Education and Culture Ministry. Politic and Social Science Faculty of Riau University always improve its service quality day by day.

Policy communication becomes the indicator of whole service implementation. The Minimum Service Standard of Riau University shows the accountability and transparency of Faculty management.

This interview result from the Vice Dean I of Politic and Social Science Faculty of Riau University clarified about the Minimum Service Standard implementation of Academic Unit of Politic and Social Science Faculty of Riau University.

“... standar pelayanan minimal bidang layanan akademis pasca BLU, hampir tidak diketahui oleh staf layanan, jika di kantor lain ada smacam flow chart, namun tidak di FISIP, prosedur layanan harusnya sudah lama dirancang oleh PD II FISIP, yang berisi syarat pelayanan, prosedurnya seperti apa, memang harus ada ketentuannya. ",

Goes along with it, The Chairperson of Administration Unit of Politic and Social Science Faculty of

Riau University, Mr. Masriful, S.Sos said that:

" saya sendiri belum pernah melihat SPM, sosialisasinyapun belum pernah saya dengar, FISIP

sendiripun tidak ada SOP, namun pelayanan harus tetap jalan sebagaimana tuntutan pelayanan prima agar semua urusan surat menyurat dan urusan akademis lainnya selesai, FISIP sendiri dalam memberikan pelayanan kepada mahasiswa hanya menggunakan Blangko Pelayanan yang diisi oleh mahasiswa kemudian baru diproses oleh staf jurusan/prodi, secara SDMpun memang kita belum siap, jumlah PNS di FISIP belum mampu meng-cover pelayanan akademis, oleh sebab itu FISIP saat ini punya \pm 70 tenaga honorer (staf dan security), mengingat jumlah staf tidak sebanding dengan jumlah mahasiswa yang dilayani, sebab dalam setahun jumlah mahasiswa yang masuk lebih jauh jumlahnya daripada yang lulus, rasio antara dosen dan mahasiswapun untuk saat ini kurang dari harapan, oleh sebab itu untuk kedepan masih harus dilakukan perekrutan, namun saat ini siap tidak siap kita sudah merupakan Badan Layanan Umum, namun sepertinya dalam menjalankan kegiatan pelayanan dalam bidang akademis masih jauh dari harapan, salah satu 
contohnya tidak adanya koordinasi yang baik antara pihak Fakultas dengan Rektorat sendiri dalam beberapa kegiatan seperti wisuda, beasiswa, yudisium dan lain-lain, semua sudah ditetapkan waktunya tetapi pada kenyataannya tetap mengutamakan /mempertimbangkan rasa kemanusiaan, jadi kegiatan tersebut bisa berjalan berhari-hari tanpa batas yang pasti, akibat dari ini semua pekerjaan semakin banyak dan menumpuk,...”

As a university with Public Service Unit implementation, all of the work units in Riau University should lead the quality service based on the Minimum Service Standard. According to Government Regulation No. 23, 2005, Minimum Service Standard is a specific technique relates to indicator of minimum service given by Public Service Unit to public. It means that Riau University especially Politic and Social Science Faculty must implement the easiness, accuracy and velocity service to the students such as Academic Administration Service. Unfortunately, there is no significant improvement in Minimum Service Standard implementation. It is stated on the interview result from the Chairperson of Academic Unit of Politic and Social Science Faculty, Mr. Zulkarnein.

" belum ada perubahan yang siqnifikan dengan disandangnya status BLU khususnya di FISIP UR dalam pelayanan akademis, mengingat timpangnya rasio ideal luas gedung dengan jumlah mahasiswa yang ada, sehingga sejak semester Ganjil TA. 2013/2014 hingga saat inipun kita masih menggunakan Gedung Pasca Sarjana (S2) untuk perkuliahan S1, padahal gedung tersebut sudah jelas peruntukkannya, begitu juga dengan timpangnya rasio antara jumlah dosen dengan mahasiswa, bahkan ada keluhan dari dosen yang mengajar 200 orang mahasiswa dalam satu kelas, jika dihitung berdasarkan rasio harusnya dosen tersebut dapat 5 kelas, mengingat minimnya sarana, hal ini didukung dengan kurang maksimalnya tata kelola/manajemen, sarana/prasarana minim seperti kurangnya jumlah in focus, kamar kecil (WC) yang kurang memadai/tidak terawat..."

Minimum Service Standard is expected to be the reference of management implementation either in academic unit or in management. Besides that, Standard Operational Procedure is one of the basic references of daily activities in Faculty. It will be done by all of the staffs in Riau University. In fact, there is no significant improvement shows by Politic and Social Science Faculty of Riau University in implementing the service.

It is also mentioned by the staffs of Academic Service of Public Service Unit of Politic and Social Science Faculty. This following script is the interview result from Mr. Teguh Widodo, the staff of Academic Service of Public Service Unit of Politic and Social Science Faculty.

" saya bekerja sebagai staf layanan akademis FISIP \pm 10 tahun, tidak ada perubahan pasca

BLU, sama saja, sebelum tahun 2000 pelayanan dilakukan oleh Fakultas, sejak tahun 2000 baru pelayanan diserahkan pada Jurusan/Prodi masing-masing, namun dari dulu hingga sekarang tidak ada SOP yang khusus mengatur layanan administrasi akademis, tidak pernah ada sosialisasi penerapan SPM pasca BLU, saya tidak pernah tahu apa itu SPM, pelayanan administrasi akademis disini sampai pada proses pengarsipan dilakukan secara turun temurun dari dulu hingga sekarang, arsip mahasiswa terakhir yang tersimpan dirunagan ini adalah arsip mahasiswa TA. 2007/2008, selebihnya diikat diikat dan disimpan digudang belakang, SOP kita buat sendiri jadi tidak heran jika SOP per Jurusan/Prodi itu berbeda-beda, pelayanan surat-menyurat biasanya dilakukan minimal 3 hari, itupun jika pimpinan berada ditempat, sebab model pelayanan saat ini jauh dari harapan, masih menggunakan model satu pintu, dimana surat masuk disitu juga surat keluar, didukung dengan kondisi ruangan dengan sarana yang jauh dari harapan, belum memenuhi standar pelayanan ISO, posisi pelayanan kurang nyaman, mahasiswa selaku costumer berada diluar sementara stafnya didalam ruangan, begitu juga untuk prasarana lainnya seperti tinta printer dan lainnya disaat kita butuh stok kosong, mestinya Fakultas mesti suplay tiap bulan untuk 
menunjang pelayanan. untuk pedoman dan prosedur yang dibutuhkan oleh mahasiswa kurang ter-informasi di biro pelayanan, jadi untuk urusan KKN mahasiswa diarahkan ke LPM, untuk urusan beasiswa kita arahkan ke Bagian Kemahaiswaan, jadi mahasiswa kerap dibuat mondarmandir. "

Implementation of policy is basically a way for achieving the goal. According to Merilee S. Grindle in Riant Nugroho (2004: 174), the success of implementation of policy is determined by two variables. They are "content of policy" and "context of policy or context of implementation".

\section{Variable of Content of Policy}

Implementation of policy is basically a way of achieving the goal. So, it is very important to concern on the content of the policy to realize it in an action. The variable of content policy meant is as follows.

\section{a. Interests Category Influenced}

The interests' of Riau University based on the Government Regulation No. 23, 2005, about Financial Management of Public Service Unit is implementing the duty and role of Riau University as the public service implementation to the students or public. So, the interests' category influenced Minimum Service Standard implementation of Postgraduate Public Service Unit in academic service according to Mr. Yoserizal, the Vice Dean I, is as follows.

" tidak ada kepentingan politik, SPM hanya untuk memaksimalkan kinerja pelayanan dengan tujuan efisien dan efektivitas. ”

Besides that, the lecturer of State Administration and the Chairperson of Technical Implementer Unit of Public Subjects, Dra. Endang Sulistyaningsih says that:

“.... kepentingannya untuk meningkatkan mutu pelayanan kepada stakeholder yang terlibat,tersosialisasi dengan baik,diadakan pelatihan untuk peningkatan SDM, ter-evaluasi dengan baik, dan terakhir harus ada kepuasan dari stakeholder. ."

In accordance with Government Regulation No. 23, 2005, about Financial Management of Public Service Unit relates to Chapter III, article 4 section 4 , about one of administrative requirements in administering the Public Service Unit of Riau University is Minimum Service Standard implementation. It will influence several affairs such as Rector, Vice Rector I, Academic and Students' Affairs Administration Bureau, Cooperation and Development Unit, Vice Dean I of Faculty, and Academic Administration Staffs of Riau University.

This following script is the result of interview from Mr. Zulkarnein, the chairperson of Academic Sub Unit of Politic and Social Science of Riau University.

" belum ada sosialisasi SPM sejauh ini, SOP di FISIP pun tidak jelas, jadi semua saya buat sendiri, jadi rincian tugaspun saya menggunakan acuan dari Menteri, prosedur pelayanan mesti dalam bentuk SOP, namun kenyataannya prosedur pelayanan administrasi di FISIP tidak tertulis dan masih menggunakan pola lama, dan seharusnya kita tahu siapa yang duduk dalam penyusunan SPM, namun sepertinya siapa yang ditunjukpun kita tidak tahu. "

From all the interview results above, it can be seen that there is a policy maker's affairs, the rector of Riau University, because the Minimum Service Standard does not implement in all elements yet. It is actually the guidelines in designing a plan, minimum service implementation, the basic principle for developing a program, resources, and service procedure and its evaluation. 
Furthermore, based on the Government Regulation No. 23, 2005, it can be concluded that Riau University has a duty in implementing the service to students and public. It should be a Minimum Service Standard as the guidelines. In addition, the success of Riau University in improving the internal and external quality will lead the success of financial autonomy implemented by Riau University towards the flexible education institution.

\section{Implementation of Communication Policy of Academic Unit}

All the Units and Bureaus under the Vice Rector of Academic responsibility such as Academic Administration and Students' Affairs Bureau, Registration and Statistic Unit of Riau University, Education and Cooperation Unit of Riau University must implement the policy communication.

Academic Administration and Students' Affairs Bureau of Riau University has a responsibility to organize and set the administration guidelines based on the regulation assisted by Registration and Statistic Unit and Education and Cooperation Unit for academic administration implementation in Riau University. Development and Cooperation Unit coordinate the Monitoring and Evaluation Unit to monitor the process of Minimum Service Standard implementation both in Faculty and University.

From the above phenomenon, policy communication using Form has lack of responses from the students. It should be a service procedure contains of service types, time consuming, and budget. It is used for anticipate and control service process. It may balance the administration service in every Program of Study in Politic and Social Science Faculty. There are some problems also found in course activity such as the numbers of Course Credit, limited facilities, course schedule, a lot of teaching time, etc.

\section{Power Category, Affairs, and Policy Communication Strategy}

Power is a life goal of many people. With a power, people may express his/her affairs. Rector has a responsibility to build a team for designing Minimum Service Standard at Public Service Unit of Postgraduate Program. In line with it, Mr. M. Tang, the Secretary of Public Service Unit says:

" untuk kedudukan siapa yang membuat SPM adalah ditentukan oleh Rektor selaku pimpinan.

Masing-masing Fakultas mengirimkan wakil untuk ditempatkan sebagai tim persiapan PK-BLU yang kemudian dirapatkan di senat UR. Jadi Rektor memilih siapa yang ditugaskan untuk membuat/menyusun Standar Pelayanan Minimal yang dianggap berpotensi menyusunnya. Dan kemudian SPM ini akan ditandatangani oleh Rektor selaku pimpinan lembaga. "

There should be a main framework as an operational guideline to run an optimal program implementation in Academic Administration Service of Politic and Social Science Faculty. It is mentioned in National Education Minister Regulation No. 51, 2009, about the Minimum Service Standard at Riau University. One of the indicators is course monitoring implementation to monitoring evaluation.

The less of Politic and Social Science Faculty seriousness in course monitoring implementation caused the less implementation of Minimum Service Standard in course service implementation.

This following script is the result interview from Secretary of Study Program of State Administration, Mr. Dadang Mashur:

"..............awalnya monitoring perkuliahan merupakan komitmen bersama antara pimpinan, petugas pelaksana dan dosen, namun pada kenyataannya sebagian dosen tidak cukup dewasa dalam menjalankan tugasnya, sehingga jika terjadi kesalahan tidak mau menerima dan pihak pelaksana (tim monev) bekerjapun lebih banyak segannya, dulu sempat ada tim monev, ada laporan tertulis, terdapat temuan, namun pada kenyataannya tidak ada respon dan tidak diproses pihak fakultas, jadi monitoring dulu terkesan formalitas saja, padahal tim tersebut dapat membantu dosen dalam menjalankan proses belajar mengajar seperti misalnya memantau kondisi ruangan, 
pertukaran jam mengajar dan lain-lain, apalagi pada saat ini tim monev tersebut sangat dibutuhkan mengingat jumlah mahasiswa yang semakin banyak.... ”:

From the phenomenon, it was found that there are some stakeholders who prioritize his/her own interests'. It can be seen from the unwell-implemented Minimum Service Standard in Riau University. Related to students' recruitment capacity, there was no good communication between Faculty and University. It caused an unbalance ratio of lecturer and students. It can be concluded that the Minimum Service Standard defines as the symbol of administration requirements in implementing the public service unit because there is no serious application of the policy.

\section{The Factors Influence the Minimum Service Standard Implementation at Postgraduate Program} Academic Service of Public Service Unit of Politic and Social Science Faculty of Riau University

In accordance with the significant improvement in Politic and Social Science Faculty of Riau University, it is reasonable that Politic and Social Science Faculty do the administrative consolidation. It aims at growing up the quality faculty by utilizing all the resources leading to the academic excellence.

\section{Facility Availability}

The available and qualified facility to support teaching and learning process is an absolute requirement for mission implementation and vision achievement. In this context, the main requirement is chairs, whiteboard, OHP, slide projector, in-focus, and sound system.

There are 1100 chairs in 18 classrooms. This numbers of the chairs is less than the students' numbers. Every classroom has a whiteboard and every lecturer has his/her own board marker.

Benny Faizal, the Academic Information System operator, organized the course schedule of Politic and Social Science Faculty. It was hard for him to schedule the course because the room availability. It can be seen from the following interview result.

"jika dilihat dari konteks ruangan, jumlahnya sangat terbatas, kapasitas ruang tidak sama, jadi

lumayan sulit untuk mengaturnya, seharusnya penyekatan ruangan bisa diefisienkan sebab kita tidak dapat memprediksi berapa banyak mahasiswa dalam satu kelas disaat pengisian portal berlangsung.

It influences the course process. It is supported by the result of interview from a student.

" kondisi tiap gedung berbeda-beda begitu juga dengan fasilitasnya, Gedunga A dan B lebih kecil, saya sampai angkat bangku karena kursi yang tersedia tidak cukup, petugas yang ngi-dupin in-focus pun jarang standby, jadi tidak jarang kami cukup lama menunggu, tidak ada perbedaan fasilitas antara reguler dengan nonreg, saya mahasiswa nonreg, udah bayar mahal, tapi dalam semua urusan diperlakukan sama.

The number of chairs in the library is also commented by the students. Dara Yulianti, a student of International Relationship Program says that the library has lack of chairs.

“... jumlah kursi saya rasa minim, bahkan tekadang saya harus menunggu diluar sampai pengunjung yang lain keluar.

Pertaining to the teaching method development, there are many lecturers use in-focus in the process of teaching and learning. Every classroom has an in-focus. It means that there are 18 units of in-focus available for supporting the mission implementation and vision achievement.

Sound System is an important facility to support the teaching and learning process. Ideally, one room has its own sound system. Service counter of Politic and Social Science Faculty functions to limit 
the interraction between students and service officers. Unfortunately, the available service counter is not maximal yet.

\section{CONCLUSION}

Based on the background of the problem and discussion above, it can be concluded that; 1) the students' number of Faculty of Politic and Social Science is getting improve year by year, 2) policy communication implementation at Postgraduate Program Academic Service of Public Service Unit of Politic and Social Science Faculty of Riau University is poor because the lack of lecturer's number in each Program of Study. It causes the lecturer's workload (credits) is over in every semester. It is not appropriate with the Government Regulation No. 37, 2009, 3) the lack of hardware in the process of administration service causes the system operator loss the time. In addition, there is no Standard Operational Procedure for service officers in implementing the academic administration service

\section{BIBLIOGRAPHY}

[1]. Agus Dwiyanto (2008) Mewujudkan Good Governance Melalui Pelayanan Publik, Yogyakarta : Gadjah Mada University Press

[2]. Agus Dwiyanto (2010) Manajemen Pelayanan Publik : Peduli, Inklusif dan Kolaboratif, Gadjah Mada University Press, Yogyakarta

[3]. AG. Subarsono (2005) Analisis Kebijakan Publik, Konsep, Teori dan Aplikasi, Yogyakarta : Pustaka Pelajar

[4]. Amin Abdullah (2006), Pola Pengelolaan Keuangan Badan Layanan Umum (PPK-BLU), Ygyakarta.

[5]. Ahmad Ainur Rohman dkk (2010) Reformasi Pelayanan Publik, Malang : Averroes Press

[6]. Buku Pedoman Fakultas Ilmu Sosial dan Ilmu Politik Universitas Riau, Pekanbaru,

[7]. Budi Winarno (2004), Teori dan Proses Kebijakan Publik, Yogyakarta : Media Pressindo

[8]. Dini Oktarina, Implementasi Standar Pelayanan Minimal (SPM) Bidang Layanan Administrasi Akademik di Universitas Riau Pasca Badan Layanan Umum (BLU), FISIP - Universitas Riau, Skripsi, 2011

[9]. Lijan Poltak Sinambela, dkk (2006), Reformasi Pelayanan Publik, Teori, kebijakan dan Implementasi, Jakarta : PT. Bumi Aksara

[10]. Merilee S Grindle (1980), Politics and Policy Implementations in the third word, Princeton University Press : New Jersey

[11]. Moh. Yamin (2009), Menggugat Pendidikan Indonesia. Yogyakarta : Ar-Ruzz Media, 2009

[12]. Mahmudi (2005), Manajemen Kinerja Sektor Publik, UPP AMP YKPN, Yogyakarta 
[13]. M. Nazir (2003) Metode Penelitian, Ghalia Indonesia, Jakarta

[14]. McLeod, Raymond, Jr, Sistem Informasi Manajemen, Jilid I, Edisi Indonesia, Jakarta, PT. Prenhallindo, 1996

[15]. Nagi, Hessel S Tangkilisan, Manajemen Publik, Gramedia, Jakarta, 2005

[16]. Pandji Santosa, Administrasi Publik Teori dan Aplikasi Good Governance, Bandung : Refika Aditama, 2008

[17]. Priyono Dwinugroho, Workshop Badan Layanan Umum, Jakarta, 2008

[18]. Prof. Dr. H. Ismail Nawawi, MPA, M.Si, Analisis, Strategi Advokasi Teori dan Praktek, Surabaya : PMN, 2009

[19]. Pengelolaan Keuangan Badan Layanan Umum Universitas Riau, Rencana Strategis Bisnis Universitas Riau Tahun 2010 - 2014

[20]. , Pola Tata Kelola Universitas Riau, 2009

[21]. Tim Prosedur Operasional Standar (2009) Badan Kerjasama dan Pengembangan Universitas Riau, Prosedur Operasional Standar : Perkuliahan, Akademis, Kurikulum dan Kemahasiswaan

[22]. Tim Prosedur Operasional Standar (2009) Penelitian dan Pengabdian, Sarana dan Prasarana

[23]. Tim Prosedur Operasional Standar (2009) Tata Pamong dan Managerial, Keuangan dan Sistem Informasi

[24]. The Liang Gie (1988) Administrasi Perkantoran Modern, Yogyakarta, Penerbit Supersukses \& Nur Cahaya.

[25]. Riant Nugroho (2004) Kebijakan Publik Formulasi, Implementasi dan Evaluasi, Jakarta ; PT. Gramedia.

[26]. Renstra Bisnis Universitas Riau 2011-2014, Cetakan Pertama : Desember 2012

[27]. R.L. Lineberry (1978), American Public Policy, New York : North Western University Harpen and Row Publisher.

[28]. Solichin Abdul Wahab (2008) Pengantar Analisis Kebijakan Publik, Malang; UMM Press.

[29]. Solichin Abdul Wahab (2001) Analisa Kebijakan dari Formulasi Ke Implementasi Kebijakan Negara, Bumi Aksara ; Jakarta.

[30]. Standar Pelayanan Minimal Universitas Riau

[31]. Winarno Surakhmad (1989) Pengantar Penelitian Ilmu Dasar Metode Teknik, Bandung ; Tarsito. 
[32]. William N Dunn (1999) Analisis Kebijakan Publik, Yogyakarta : Gadjah Mada University Press.

[33]. William N Dunn (2003) Analisis Kebijakan Publik, Yogyakarta : Gadjah Mada University Press. 